information,' which (whether it was the intercepted letter of 1647 purporting to reveal an Irish plot, or the information laid in 1670-1 by Edward Fitzgerald against Captain Walcot) is of the same nature as those we have mentioned, as well as the so-called 'Rich. Green's information 1676,' published three years later as Part IV of Tonge's 'Popish Plot' and included in his 'collections' regarding the Plot. ${ }^{9}$ It seems probable, therefore, that it was from a combination of these sources: first, the general knowledge each had of the earlier Restoration plots; second, printed material relating to them; and third, the narratives of the Gunpowder and Habernfeld conspiracies, rather than from the catholic connexion of Oates, that the document was concocted which played such a part in affairs after 1679 . It was, in fact, less an 'invention,' as it has generally been called, than an adaptation of old stories to new circumstances. ${ }^{10}$

W. C. Аввотт.

\title{
An English Sailor among the Chouans
}

Tre suspicions attached to the service on which Captain John Wesley Wright was engaged at the time of his capture by the French in 1804, and the legend that before the defence of Acre he was landed by Sir Sidney Smith near Alexandria, 'not openly as a British naval officer, but bearded, moustachioed and shawled $\dot{a}$ la Turque, for the express purpose of obtaining valuable information,' 1 are somewhat borne out by the documents printed below. The first two are copies of Wright's letters to Sir Sidney Smith made by order of the latter for the Prince de Bouillon at the time of their receipt-the letters from ' J. W. W.-Mercure' to which Smith's communication of 9 April 1796, printed in this Review in July 1908, was the answer. They are of interest alike for the history of the Chouannerie in the Côtes-du-Nord, and for the slightly mysterious career of Captain Wright himself.

Wright was landed from the 'Diamond' near Erquy the night previous to Sir Sidney's successful attack on that place (17 March 1796). ${ }^{8}$ The immediate object of his mission was, clearly, to secure for Sir Sidney the assistance of the Chouans; but he was also intended, in Smith's own words to the Prince de Bouillon, ' to reconnoitre and give us his guidance in our military expedition if he could not muster

- J. Pollock, Popish Plot, p. 11.

10 'That Tonge was Oates' Pilot is certain,' 8ays North, in the Examen, and 'if the Consideration of Things themselves and the nature of them will not assigt us in the Resesich of these Trutbs there is no remedy.' 'He who would find the origin of the story,' says L'Estrange, 'shall never need to Consolt the Records either of Salamanca or St. Omers,' and quotes Simpson Tonge's account of the fabrication of the Plot, which seems to me on the whole trae.

' Howard, Memoirs of Sir Sidney Smilh, i. 162.

- For which see Barrow, Life and Correspondence of Sir Sidney Smith, i. 178-182. and Howard, i. 91-97. The date of Wright's landing is fixed by bis letter of 29 March below, p. 132 ; cf. p. 137.

vol. xxv. - NO. Xcirr. 
a co-operation from the Chouans.' ${ }^{3}$ When Wright found himself unable to gain any reinforcements for the attack-for which, as it proved, they were not needed-he not only turned his energies into a personal investigation of the Royalist position in the neighbourhood, but extended his rôle so far as to make the enterprising suggestion of bribing the governor of St. Malo. What Sir Sidney thought of this project does not appear, but with regard to his protege's military ardour he expressed a hope to Bouillon that 'Wright's zeal in this way may not carry him too far; he has been at it with a musquet in his hand already ' 4 The prince had made Wright's acquaintance in the previous autumn. 'This serves,' wrote Sir Sidney from the 'Diamond,' off Guernsey, on 24 September 1795, ' to introduce my secretary, Mr. Wright, who [sic] I present to you, as my friend and confidential man, au fait of all circumstances of our late operations, hopes, and expectations ' $;{ }^{5}$ and Bouillon has endorsed the letter as 'answered by Mr. Wright 26 September.'

The royalist division of Dinan, in which Wright had for thirteen days been pursuing his investigations, ran along the cosst from St. Medo to Erquy, between those of the Clos-Poulet and of St. Brieuc, and was composed of thirty-four parishes. ${ }^{6}$ It was commanded at this time by a Breton émigré, the chevalier Victor-Amédé Collas de la Baronnais-' Victor'-a soldier who had seen service at the siege of Gibraltar and in the army of Condé. He succeeded as chef de division his younger brother, Malo, killed the previous July; two other brothers, one of whom was killed, served in the same division. ${ }^{7}$ Many of his letters are to be found among Puisaye's papers, ${ }^{8}$ but unfortunately there are none between March and July 1796. 'Saladin' was his lieutenant, the chevalier Servan-Gabriel de Gouyon, of a family which furnished many champions and victims to the royalist cause. The chef de canton, whose letter Wright speaks of enclosing to Sir Sidney was the famous 'Richard,' or 'Coour-de-Lion,'

- Sir Sidney Smith to the Prince de Bouillon, 'Diamond,' off Cape Barfleur, 8 April 1798 : P.R.O., Home Office Papers, Various, Bouillon Correspondenoe, 8.

4 Ibid. Thet Sir Sidney Smith entertained for Wright an almost romantic regard is abundantly proved. He publioly testified in 1805 that " his manners are of a perfect gentleman, his abilities of the first class, and his bravery only equalled by his generosity and hamanity. . . . Indeed, I have not words to express my admiration of his oharacter' (Barrow, ii. 96). 'Oui earum rerum qum ad summum gloriæ fastigium perducunt nihil preter occsionem defuit' runs the insoription on the monument which the admiral erected in 1816 to his friend's memory in Père-Lachaise. Wright was not alweys so well looked on by those in euthority.

- Bouillon Correspondence, 8.

- Add. MS. 8022, f. 131, Viotor Collas de la Baronnais to Woodford, 27 July 1795.

- Another brother, Armand-Fidele, fell by Chateaubriand's side at the siege of Thionville in 1792 . Vietor, who was born in 1764, died of apoplexy in 1835 : Lovot, Biographie Brelonne.

- Add. MS. 8022, ff. 64-127.

- Memoires du Colonel de Ponsbriand, p. 532, and 'Saladin's' letters, Add. MS. 8022, ff. 165, 161. 
whose real name was Stevenot. ${ }^{10}$ Sir Sidney sent on 'Richard's' letter to Bouillon on 14 April, terming him

a new acquaintance to me but a man who [sic] I suppose you know and therefore you are the fittest person to decide on the propriety of furnishing him to such an extent as he wishes and you will tell me the degree of confidence to be placed in his promise of co-operation. ${ }^{11}$

Whatever may have been the Chouan's demands or proposals, they were cut short by the capture of the 'Diamond's ' commender five days later. 'Send all letters to me poste restante St. Marcou,' concludes this, Sir Sidney's last letter to Bouillon ; but ' poste restante Paris' would have been more accurate, had the writer but known.

These thirty or so characteristic letters of Sir Sidney Smith's among the Prince de Bouillon's papers serve to elucidate several of the English commodore's projects for intercourse with the Chouans. It appears by the way that ' Le Cure' who had an interview with Captain Graham Moore on the beach was not a Chouan, as the present writer wrongly supposed,,$^{12}$ but a bona fide priest. Sir Sidney writes on 4 April from St. Marcouf to announce

the news of the good curate of Barly's safety chez lui or rather at his village, for the Presbitère is burnt; he was landed from the Syren at the right place before I arrived, and I sent Captain Moore to meet him on the same rendezvous at the appointed time, which was manged [sic] with punctuality and address on both sides on the 31st. You are used to these nocturnal meetings, but it was new to them, the curate not expecting Moore to come himself had a letter ready for him besides the one for me.

As to the meeting with Frotte which Sir Sidney desired to compass, the same letter contains intelligence of the arrival of a missivethrough the agency of Tromelin and the 'curate of Vieuville' 13

from V. de Maigray (du Menil) opening the communication on this side direct with St. Marcou, through which I am in hopes to be able to receive Frotte's wishes as to the point of rendezvous on the beach.

I have written to Frotte [continues Sir Sidney] in consequence of Mr. Windham's suggestion begging him not to make any efforts beyond his powers and assuring him of my patienoe and the firm foundation of the rock to which he points his course even if the frigates should part from their anchors. ${ }^{14}$

10 A few of his letters are also to be found in Add. MS. 8022. He is officially decoribed, about ten years lster, in a list of signalements de Ohowans among Puisaye's pepers, as 'bian fait, oheveux chetains, visage ovale, le nex un peu long, prenent du tabec, yeux vifa, visege coloré, se balanģant un peu en marohant, il n'a auoun doigt à la main gauche, il n'y a qu'un moignon, étant tombé de son berceau dens le feu étant enfant, cependant il fait parfaitement lo coup de fen, joue aux cartes, etc., homme sanguinaire, il a commis des exade den l'arondissoment de Dinan' : Pontbriand, p. 532.

11 Bonillon Correspondences 8

13 Ante, vol rxiii, 535. 13 ? Vierville.

14 Bouillon Correspondence, 8. 
Presumably the 'rock' is St. Marcouf. The next letter (of 9 April) while telling Bouillon that the writer occupies the ground 'prouling about in the offing all night seeking whom we may devour,' thanks him for his letter, 'and its very gratifying accompaniment,' i.e. Wright's letter or letters-

which not only affords me news of my friend Wright['s] safety, but also of the probability of his joining me by way of Frotté's headquarters, which I encourage by a letter enclosed. ${ }^{15}$ I beg of you to forward it by the first opportunity through Boisguy the medium he himself points out, under the nom de guerre $J . W . W$. Mercure. ${ }^{16}$

Since du Boisguy was the chef de division of Fougères, and Puisaye's headquarters were usually in the neighbourhood of that town, this would be the natural course to take, as Wright had announced his intention of going on to Puisaye. But whether he ever reached the Breton general, or whether he went into Normandy to Frotté, and when and where he rejoined the 'Diamond ' (save that it was before 19 April), is still a mystery.

It remains to add, in extenso, the extract from another letter of Wright's, also bearing date 30 March 1796, which Sir Sidney saw fit to send as intelligence to the Admiralty. It is clear either that Sir Sidney did not send Bouillon a copy of the whole of Wright's letter of 30 March, printed below, or that there was another letter, for Wright's directions as to sending correspondence do not occur in the former as we have it.

D. K Broster.

I.

[Copy]

\section{John Wesley Wright to Sir Sidney Smith.}

- Parigh of Peramé, 3 miles from St. Malo, 29 March 1796.

My Dear Sir Sidney,-I have been long impatient for an opportunity of putting an end to your suspense as to my safety, and giving you a sort of Journal of my proceedings since I left you on the 16th instant: the intended departure of a boat this evening with despatches to the Prince de Bouillon gives me time to say but a few words.

I arrived after half an hour's walk from the Coast, at the village of Turo (about $\frac{1}{2}$ a mile from Herqui) and delivered your letter to Monr. de la Rue, formerly l'Industrie but now le Comte de Savoye. As there were no Royalists in activity in his Canton he could not engage to second you by land but despatched a person to the Chef de Division in the neighbourhood of La Foret de la Huneauday about 12 miles distant, who might probably have it in his power to bring soms troops to the point proposed. Le Comte de Savoye assured me that Herqui had been reinforced from Pleuneuf, ${ }^{17}$ etc., for the protection of the convoy; that the Battery contained from 60 to 100 men and that Patroles of 15 to 20 men prevented all communication

15 The letter of the same date to Wright, printed ante, vol. xxiii. July 1908.

16 Bouillon Correspondence, 25.

17 Pléneuf. 
during the night between the villages and the Batteries; that the peasantry could not quit their Houses under fear of being arrested as suspected persons, and that suspicion and vigilance conspired to render my Project impracticable. I urged him to procure me a Guide into the Battery, but he would not hear of it, saying that it was impossible to find a man who would undertake it under the existing circumstances. I did not abandon my project until it was 5 o'clock and the approach of day dictated the necessity of an immediate retreat. I went to Portual, the point of Rendezvous for the Boat where I waited without effect till it was no longer safe; on my return to the village I met some fishermen already going to their occupation. My disappointment at first gave me great pain lest depending on the success of my negociation with the Royalists you might have been induced to risk more than you otherwise would have been disposed to do, but the Brilliant conduct of our brave fellows soon put an end to my uneasyness leaving me no other subject of regret than the impossibility of affording them assistance or of partaking in their honours. I was at the Village behind the hill on which you spiked the guns and could not judge of that operation but by report, which was highly Gratifying to me and honourable to those employed; my position however afforded an excellent view of the conflagration and the Gallant approach of Boats under the fire of musquetry and Grape, all the vessels are destroyed except one very small Lugger and the few articles of Wine and Arms that were saved, served only to make the Republican troops Drunk, and to minister to the necessities of the Royalists for each Soldier had latterly a Bottle hid under his Coat with a String tied round the neck of it for the purpose of dipping into the Butts of Wine to allay their thirst under the fatiguing duty of saving what was within their reach, while on the other hand the agents of my friend the chef de Canton were employed stealing the arms as they were brought on shore for the use of the Royalists. I shall reserve further details of this Affair, until I have the pleasure of meeting you.

Soon after the furious fusillade, when the Boats came at night to finish what was yet to be done, I received notice that the Royalist chief was arrived and desired to see me; he proved to be the chevalr de Gouyon, an excellent brave lad in whose report of the state of the Royalists I have great confidence, and as I have had an opportunity of seeing him in action and travelling with him to St. Servan I have bocome acquainted with his character. I enclose you 2 lettèrs from him No. 2 and 3 a letter from the Chief of his Division No. 1 a letter from Ie Comte de Savoye No. 4 -No. 6 a letter from the Chief [sic] de Canton de Plubalais-you will receive other enclosures No. 1 to 6 will explain themselves. I shall take the first opportunity My Dear Sir Sidney to say more at large and more intelligibly - time and Fatigue interfere with my wishes now-the Royalists only want arms and Ammunition-I have fought with them successfully against the Blues on the publick Road between Lambale and Maintignon ${ }^{18}$ they want officers extremely in Victors army some poor fellows wounded, are forced to continue their toil for want of Officers.

I go to-morrow to the 'Conseil General' at Fougeres as I think I can do some good-I am become somewhat acquainted with Charackters 
already and I yield only to the wishes of 2 or 3 Person who think I can be of Service. The letter No 5 contains a List of wants, the small List at the Bottom may be immediately supplied if you have not desposed of the means the larger Part I wish to say more concerning before (you make it known

$$
\begin{aligned}
& \text { Yours, my Dr Sir Sidney } \\
& \text { very affectionately } \\
& \text { J. W. WRIGHT. }
\end{aligned}
$$

This Letter I entreat may be kept to yourself entirely-you shall not be long without one that I shall be less asham'd to have made use of to any one you please.

J. W. W.)

[Note by Sir Sidney Smith:]

Mr. Wright must have alluded to the writing and not to the style or matter in the postscript therefore it is recopied from his hasty broullon and it is hoped his wishes are not contradicted in putting it thus under the Eye of our common friend. ${ }^{19}$

II.

John Wesley Wright to Sir Sidney Smith:0

[Copy]

Parish of Parame, 3 miles from St. Malo. 30 March 1796.

My Dear Sir Sidney,-I found it impossible, the ${ }^{21}$ to procure you the Co-operation of the Royalists, in time for your brilliant Coup de main, at Erqui, \& indeed the Issue prov'd that my ill success, was of no great Consequence, for all that you cou'd have propos'd to yourself, from their aid, was execut'd without it, unless we take it into the Estimate, the probable Destruction of 2 or 3 Hund $^{\text {a }}$ Republicans, who might have perish'd if the Royalists had taken them in the rear.-I shall reserve details of that Affair, for an interview with you, having matter to communicate, that is of a much more pressing Nature.-After having gone twice, to the point of rendezvous, to embark, without finding the Boat, I determin'd if possible to turn my Disappointment, to good Account, by taking a near View, of the Royalist Armies, to enable me to speak of their State, numbers and position, with some certainty, and then rejoin you, if you continued in the Neighbourhood of Chosée, ${ }^{22}$ from some point near St Maloes, or if you have quitt'd that Station, from some Point near St Marcou. I have executed so much of my plan, as to have come thus far, with Detatchments, of the Royalist Armies, and to have interview [sic] with some of the chiefs.-(Saladin) Le Chev $^{r}$ de Guyon, (Victor) Le Chev ${ }^{r}$ De Baronais, appear to me, to have merit deserving Confidence, and abilities, for the species of war, which exists in this country, beyond what I have discover'd in any others, it is true, I have not yet seen very many.-Their Division is better disciplin'd, and I think capable of more rapid Advancement, toward the Degree of

1" This note is in Sidney Smith's own hand; the end portion of the letterhere enclosed in parentheses - is by a different copyist from the body of the letter, which is in a large, round, laborious hand.

so Bouillon Correspondence, 31.

$\Rightarrow$ These words are crossed through. $\quad 7$ Les lles Chausey. 
military Excellence that wou'd enable them to meet the Blnes with equal Numbers in the open Feild-Their operations are at present, confin'd to Hedgework, where they lay in ambush, near the public roads, and intercept Convoys of Forage, Grain, etc etc destin'd for the Republican Troops, the activity of this small body in arms, is however, so extraordinary as to keep the Republicans, on the qui vive, and give an Impression of Numbers far above what they really are. Detatchments of $10,20,30$ and 50 on, are sent every night to lay in ambush, on the high road, between Lambale, and Plancouet, and Lambale and Maintignon, the peasantry are in that part of the Country, determined Royalists, with the exception of very few, and those few diminish dayly, by retiring into towns, thro' fear, or falling sacrifices to their erroneous principles, for the Chasseurs du Roy, spare none, whom they despair of converting, or whose obstinacy, induces them to despise a warning, de par le Roi, to quit their abode.-Denonciateurs are shot without the least mercy, or hesitation, and the Vigilance, and Numbers, of the Royalist Spies, render it nearly impossible for the Republican informers, to escape death.

I was present at an Expedition commanded by Mons Victor (Noms de Guerre) and Saladin, with 60 to $\mathbf{7 0}$ men indifferently arm'd, went to intercept a Convoy of Grain, which was to be guarded by 60 or 100 Blues, from Lambale, towards Plancouet, we paraded along the High roads, for 3 or 4 Miles, and then lay in ambush, alongside of the Hedge, on each side of the road, where we had not been long, before a Messenger arriv'd from Lambale, to announce, that after the Horses, had been harness'd and ev'rything ready for the Departure of the Convoy, the Guard, was thought insufficient, and the Departure of the Convoy, in consequence protract'd ; we then continu'd along the High road, on rising the Hill, near St. Guestin [?], we perceiv'd, a small body of blues, and retir'd into an Ambash, where we wait'd their arrival.-They met an empty Waggon, that we had just sent back to Maintignon, after destroying the load of Hay, which was sent by requisition, for the army ; from the Waggoner, it is probable, they rec'd intelligence of our position, for they seem'd to be on the Reconnoitre, as they advanc'd.-We have [sic, for 'gave'] them battle within $\frac{1}{2}$ pistol shot, and forc'd them to a precipitate retreat, after $\frac{1}{2}$ an hour ; they began their retreat, or rather flight, at a moment when the main body of our troops, were filing off to the right, to turn the enemy's left flank, and the Enemy's motions, were not immediately perceived by us, thro' the Smoke, but a small Number of our troops, who had occupied the opposite Hedge, and were clear of the Smoke, took advantage of the first favourable moment, and pursued the Enemy, near $2 \frac{1}{2}$ miles. They were 50 , of which 5 were dangerously wounded, the only one hurt on our side was my brave freind [sic], (Saladin) who was wounded in the Head, close by me, in giving the order to leap the ditch, and fall on the Enemy, the order was 3 times distinctly given, but the firing prevented its immediate Execution, and he bravely mounted the Hedge, to cause the troops to cease firing and reload; preparatory to storming the enemy's Ambush ; and received, his wound at that moment: I should not have entered so much into detail of this trifling affair, my dear Sir Sidney, but to give you an adequate idea, of the coolness of the officers, and ardour of the troops, to place it beyond a doubt in your mind, that the energy 
of the royalists, has not been falsely describ'd, and that their numbers are sufficient, to make them formidable to Republicans.-I have the firmest persuasion, that if Victors Division, had officers, and Arms, they wou'd very soon rid that Country of republicans, who even now dare not venture, to move from one Village, to another, with less than 60 or 100 Men.

The Communication between Lambale, and St Maloes, either by Plancouet or Maintignon, is interrupted, everything that is found on the road for Republican Acc ${ }^{t}$ is either taken, or destroy'd, by Victor's Division, and an acknowledgement given in writing to the carriers, in order to protect them from personal injury, and pecuniary restitution. Victor had but 5 officers, when I was with him, two of which are now wounded, and my brave freind Saladin, is for some time hors de combat. Officers they must have, and it is essential they have some military men. They call loudly for a Prince affairs are however, I think not yet suffitien[t]ly advanced; the Royalist army must have permanent Head Quarters on the Coast; and must be more generally arm'd, than it is at present, before it be prudent, to risk any Character of weight among them, and before any large body can be expected to leqve their own Foyers, to fight in distant Cantons, Magarines of provisions must be establish'd and means had to give them security, against the Enemy.-The project of paying [a] certain Numbr is not less essential, in order to organize, some Colonnes mobiles who may be mov'd to any distant point, more particularly near the Coast, where their presence would ensure the reception of Arms, of Ammunition, of which they are in extreme want. It is the practice to buy [sic, for 'levy'] Contributions, on all Persons, who have purchas'd Estates, or Effects, belonging to the Emigrants, in proportion to what they have been forc'd to pay the Republican Collectors, and it is a fact. as true as it is singular, that if the Royalist Collectors, happen to have preceeded those of the Republick the latter, do not exact any further Contribution, after seeing the Receipts of the former. The Country between [sic] St Brieuc is good with the exception of a very few Villages, near the Coast; Pleurien ${ }^{23}$ Plurenon etc insomuch that $I$ am persuaded nothing, but the apprehension of becoming sacrifices, to their principles, by the insufficiency of the Royalist force, to secure them against Republican rage, prevents them declaring themselves publickly; I intreat you Dear Sir Sidney, to make an effort, if possible, to supply Victor, with Arms, and Ammunition, in pretty large Quantities, when you appear off Cape Frehel, he will send a boat to the Ship and you can then concert measures, for the purpose-the boat will steer for the ship, and on coming near will make the Signal with the Oars, as agreed with the fishermen, near Caen. I daily see the necessity of numbers of Luggers, Cutters, and Gunboats, at your Command, to prevent all Coast communication, except for the Royalists, as St. Maloes, is now victuall'd, merely coastwise, and it wou'd be easy to starve it, by stopping the small vessels, that bring Grain, etc from Dauet $^{24}$ to St. Malo, Dauet, is between St Brieuc and Erqui. I have taken measure, to procure an interview, with the Commander-in-chief of St Malo, Genl Clincq, he is a German, and a humane man, some part of his conduct, has given an idea, that he is not a Republican at heart, he is poor, and if 
I were vested with authority to ensure him a situation, not less honourable, and a little more profitable, than that he now professes, perhaps something might be done-I will risk an interview if it is to be had and I will take the pecuniary part, of the affair, on my own risk likewise, until I have some certain authority, as to the other part, I can do no more than l'entamer à condition que. I set off in a few days, for the Head Quarters of Mons de Puisaye, where I am not without hope, of doing some good at least by impressing on those, who more immediately direct the motions, of the Chiefs, near the Coast, the resource they have at hand, in our active Squadron, none that I have yet seen, had the most remote idea of Cooperation, on the part of the Squadron.

St Maloes, is in general good, but the inhabitants are afraid of another Toulonade: however if measures were safe for a Coup, I shou'd not for a moment, hesitate to take an active part, or despair of determin'd, and successful aid, from the inhabitants.-I have seen many of them.-I will undertake anything you dictate, my dear Sir Sidney pour l'amour du jeu some persons, I have seen speak of the Clos Poulet "s with much interest, they say the possession of it wou'd reduce St Malo without firing a Gun, more of this after I have been behind the Curtain. The only thing that I fear among the Royalists, is dissention among themselves. Their Army must be organiz'd, and individual power, defined, and restrict'd-Boisguy and Frotté are excellent freinds, and neighbours, it is not so everywhere. Beleive me Dear Sir Sidney very sincerely,

Your affectionate and devoted servant ${ }^{26}$ J. W. WRIGHT.

III.

\section{Intelligence. ${ }^{97}$}

- Extract of a letter from an Emissary landed from the "Diamond," at Herqui, the night previous to the attack on the enemy's shipping there, for the purpose of reconnoitring and gaining intelligence of the Royalists and now with the Royalist army. Dated from [blank] a village in the neighbourhood of St. Maloes, 30 March 1796.'

The 'Bravoure' will sail in 8 or 10 days for Brest. I hope nothing will prevent you meeting with her, she is ill man'd carries 40 guns 12-pounders on the Main Deok ${ }^{28}$

A fleete will shortly sail for Cherbourg and Havre. I hope you will intercept them. One of our Launches with a $24 \mathrm{lb}$. cannonade 24 men is driven into Cherbourg. I trust it is not the 'Diamond's.'-I am au desespoir to hear the account of the killed and wounded on board the 'Diamond ' etc. at Herqui-20 of the Enemy's fell. Brest is Starving, this is certain. Report says that 4 sail of the Line and 6 Frigates are coming from thence to take a station near Cancale.

(Copy) W. Sidney Saith.

$\Rightarrow$ The small but very important division of the Clos Poulet extended from St. Malo down the right bank of the Rance. Much of the Jersey correspondence was carried on with the district on its coast-line between St. Malo and Cancale.

:- The excessive punctuation of this letter is evidently due to the copyist.

77 P.R.O. Admiralty, Secretary, In-Letters, 2493.

:Alas the "Bravoure" will move if I can contrive a run westward I will do it however in the interval' : Smith to Bouillon, 14 April, Bouillon Correspondence, 8. 